\title{
Batas Usia Minimal Perkawinan Menurut Perspektif Hukum Positif di Indonesia dan Hukum Islam
}

\author{
Pitrotussaadah $^{\mathrm{a}, 1}$ Mimin Mintarsih ${ }^{\mathrm{b}, 2}$ \\ a STAI Al-Ma'arif Ciamis, Indonesia; 'bSTAI DR. KHEZ. Muttaqien Purwakarta, Indonesia \\ 1 fitrohsaadah20@gmail.com;2mimin.mintarsib@gmail.com
}

\begin{tabular}{ll}
\hline & ABSTRAK \\
\hline Kata kunci: & Tingkat kedewasan menjadi acuan bahwa seseorang mampu untuk \\
Anak & melaksanakan perkawinan, dan semua pemikiran masyarakat pada umumnya \\
Dewasa & menjadikan usia sebagai ukuran tingkat kedewasaan, meskipun pada dasarnya \\
ustas usia & bertujuan untuk mengetahui konteks batasan minimal usia perkawinan \\
& menurut pandangan hukum positif di Indonesia dan pandangan hukum islam \\
& serta untuk mengetahui relevansi konteks batasan minimal usia perkawinan \\
& dengan konteks sekarang. Penelitian ini menggunakan metode penelitian \\
& deskriptif analisis dengan menggunakan pendekatan kualitatif yaitu \\
& mendeskripsikan dan menganalisis fenomena dan dokumen peraturan \\
& perundang-undangan. Hasil penelitian ini adalah batas usia perkawinan \\
& menurut hokum positif di Indonesia adalah 19 tahun, sedangkan menurut \\
& hukum islam tidak ada batasan usia hanya sampai usia baligh, dan aturan ini \\
& sudah relevan dengan kondisi saat ini. Penelitian ini diharapkan bisa \\
& memberikan kontribusi ilmiah di bidang hukum islam dan pranata sosial dan \\
& berguna untuk memberikan gambaran atau pedoman awal bagi para praktisi \\
& hukum sebagai bahan pertimbangan dalam menetapkan batas usia minimal \\
perkawinan yang disesuaikan dengan kondisi saat ini, dan juga bisa sebagai & bahan kajian untuk penelitian selanjutnya.
\end{tabular}

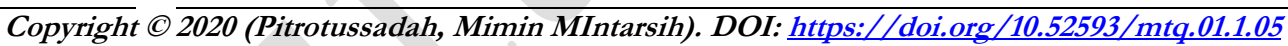
Naskah diterima: 4 Desember 2019, direvisi: 23 Februati 2020, disetujui: 27 Juni 2020

\section{A. Pendahuluan}

Manusia diciptakan oleh Allah dengan segala fitrah-Nya, baik itu jiwa, raga, dan intelektualitasnya merupakan satu kesatuan sehingga manusia menjadi makhluk paling sempurna yang diciptakan Allah diantara makhluk lainnya. Dikaitkan dengan tingkat peradaban manusia saat ini, kedewasaan selalu menjadi ukuran dalam setiap tindakan dan tanggung jawab yang diemban, sehingga kedewasaan menjadi faktor yang sangat penting dalam setiap interaksi sosial, baik yang menimbulkan akibat hukum maupun yang hanya sebatas dalam ruang lingkup hubungan masyarakat. Hampir setiap kehidupan kedewasaan selalu menjadi ukuran tanggung jawab dalam perbuatan hukum, baik itu dalam hukum positif di Indonesia maupun dalam hukum islam atau yang lebih dikenal dengan istilah mukallaf.

Keanekaragaman dalam menentukan batas usia kedewasaan diakibatkan oleh tidak adanya patokan yang dapat digunakan secara akurat untuk menentukan batas kedewasaan manusia, usia dan tindakan perkawinan memang bisa menjadi salah satu penentu kedewasaan, namun tidak selalu menjadi ukuran yang tepat karena kedewasaan sendiri merupakan suatu keadaan dimana seseorang telah mencapai tingkat kematangan dalam berfikir dan bertindak, sedangkan tingkat kematangan itu hadir pada masing-masing orang 
secara berbeda-beda, bahkan ada pendapat yang mengatakan bahwa mungkin saja sampai dengan akhir hayatnya manusia tidak pernah mengalami kedewasaan karena kedewasaan tidak selalu berbanding lurus dengan usia.

Perkawinan merupakan suatu peristiwa yang sangat penting dalam kehidupan manusia. Dasar-dasar perkawinan dibentuk oleh unsur-unsur alami dari kehidupan manusia itu sendiri yang meliputi kebutuhan dan fungsi biologis, melahirkan keturunan, kebutuhan akan kasih sayang, persaudaraan, memelihara anak-anak tersebut menjadi anggota masyarakat yang sempurna.

Perdebatan tentang batas usia anak atau batas usia dimana seseorang dianggap dewasa dalam konteks perkawinan adalah menyangkut kesiapan dan kematangan tidak saja fisik, namun juga psikis, ekonomi, sosial, mental, agama dan budaya. Hal ini karena perkawinan pada usia dini, seringkali menimbulkan berbagai resiko, baik resiko yang bersifat biologis, seperti kerusakan reproduksi maupun resiko bersifat psikologis. ${ }^{1}$

Menurut Undang-undang No. 23 Tahun 2002 tentang Perlindungan Anak kategori anak-anak adalah orang yang masih dibawah usia 18 tahun ${ }^{2}$, sedangkan menurut Undangundang No. 26 Tahun 2000 tentang Pengadilan Hak Asasi Manusia dirumuskan kategori dewasa berumur 18 tahun, dan menurut Undang-undang No. 30 Tahun 2004 tentang Jabatan Notaris, dinyatakan syarat dewasa berumur 18 tahun (atau sudah/pernah menikah) ${ }^{3}$.

Adanya penentuan batas dewasa secara normatif hukum positif di Indonesia dengan menentukan batas usia minimal orang yang bisa melangsungkan perkawinan yang diatur dalam Pasal 7 ayat (1) Undang-undang No. 1 Tahun 1974 Jo. Undang-undang No. 16 Tahun 2019 Tentang Perkawinan, dan juga dalam pandangan hukum islam yang diatur dalam pasal 15 ayat (1) dan (2) Kompilasi Hukum Islam. dari hal ini, perlu kiranya untuk mengadakan penelitian lebih lanjut tentang batasan minimal usia perkawinan dalam perspektif hukum positif di Indonesia dan hukum islam.

\section{B. Teori / Konsep}

Ada beberapa penelitian yang terkait dengan judul ini, mekipun fokus penelitiannya berbeda. Skripsi dengan judul "Batas Minimal Usia Nikah perspektif Muhammadiyah dan Nahdlatul Ulama", membandingkan antara pandangan Muhammadiyah dan NU tentang batas minimal usia nikah. Muhammadiyah lebih cenderung sepakat dengan UU No. 1 Tahun 1974 tentang perkawinan yang memberikan batasan jelas bagi laki-laki dan perempuan yang ingin melakukan pernikahan. Sedangkan NU dengan metode istinbatnya yang selalu memakai pendapat ulama terdahulu, melihat perundang-undangan di Indonesia

${ }^{1}$ Umi Sumbulah, "Ketentuan perkawinan dalam KHI dan Implikasinya bagi Fikih Mu'asyarah: Sebuah Analisis Gender", hlm 100.

2 pasal 1 ayat (1) Undang-undang No. 23 Tahun 2002 tentang Perlindungan Anak: "anak adalah seseorang yang belum berusia 18 (delapan belas) tahun termasuk anak yang masih ada dalam kandungan".

3 Andi Sjamsu Alam, "Usia Perkawinan dalam Perspektif Filsafat Hukum dan Kontribusinya bagi Pengembangan Hukum Perkawinan Indonesia”, hlm. 3.

${ }^{4}$ Asyharul Mu'ala, Batas minimal Usia Nikah Perspektif Mubammadiyah dan Nahdlatul Ulama Skripsi Fakultas Syari'ah dan Hukum UIN Sunan Kalijaga, 2010. 
yang mengatur tentang batasan usia menikah, dirasa tidak relevan dengan pendapat ulama terdahulu dalam karya-karya klasiknya. Sehingga NU tidak tidak memberikan batasan minimal usia nikah. Namun hal yang paling mendasar dalam persyaratan bolehnya menikah adalah ketika kemaslahatan bisa diraih oleh pihak-pihak yang terkait dengan perkawinan tersebut.

"Batas umur minimal Perkawinan (Studi Perbandingan Kompilasi Hukum Islam dan Psikologi)" menjelaskan secara kritik analitik terhadap pandangan Kompilasi Hukum Islam dan Psikologi tentang batas minimal umur perkawinan. Penelitian ini bersifat deskriptif analitik, yaitu menggambarkan konsep-konsep pembatasan umur minimal dalam perkawinan yang terdapat dalam Pasal 15 kompilasi Hukum Islam, kemudian dianalisis dan dikomparasikan dengan kajian psikologi. Berdasarkan analisis yang dilakukan dapat diperoleh kesimpulan bahwa pembatasan umur minimal perkawinan dalam Kompilasi Hukum Islam dimaksudkan untuk kemaslahatan keluarga dan mampu meraih tujuan perkawinan. Pembatasan ini diperlukan mengingat banyaknya perkawinan dibawah umur yang marak terjadi di masyarakat. Sehingga kalau hal ini terjadi maka tujuan perkawinan yang diharapkan tidak akan terwujud karena yang akan terjadi adalah sebaliknya, yaitu kehancuran rumah tangga atau perceraian. Dalam kajian psikologi, ketentuan umur yang terdapat dalam undang-undang maupun Kompilasi Hukum islam masuk dalam wilayah masa remaja, yaitu masa transisi menuju kedewasaan.

"Batas Minimal Usia Perkawinan Menurut Undang-undang Nomor 1 Tahun 1974 Tentang perkawinan dalam perspektif Hukum Islam dan Kesehatan Reproduksi"6 kesimpulan dari penelitian ini adalah kematangan fisik seorang anak tidak sama dengan kematangan psikologinya meskipun nak tersebut sudah menstruasi, secara mentral ia belum siap untuk berhubungan seks. Kehamilan bisa saja terjadi pada anak usia 12-15 tahun, namun psikologinya belum siap untuk mengandung dan melahirkan. Anak-anak yang berusia dibawah 18 tahun belum matang dan rentan kondisi reproduksi serta masih labil kondisi psikologisnya. Melihat banyaknya kemadharatan yang terjadi akibat pernikahan yang dilangsungkan ketika mempelai perempuan masih berusia dibawah 18 tahun, maka konsep sad adz-dzari'ah menjadi solusi yang tepat untuk diterapkan. Pernikahan dalam islam berorientasi pada kecakapan calon mempelai, dengan pernyataan baligh sebagai acuannya. Baligh berarti dewasa, kemudian disesuaikan dengan perundang-undangan di Indonesia yang mematok usia 18 tahun sebagai usia anak-anak, maka seharusnya undang-undang yang terkait dengan usia perkawinan perlu ditinjau kembali dan disesuaikan dengan kondisi saat ini.

"Usia perkawinan dalam perspektif filsafat hukum dan kontribusinya bagi pengembangan Hukum perkawinan Indonesia" " hasil penelitian disertasi ini adalah

\footnotetext{
${ }^{5}$ Agus Sanwani Arif, Batas Umur Minimal Perkawinan (Studi Perbandingan Kompilasi Hukum Islam dan Psikologi), Skripsi Fakultas Syari'ah dan Hukum UIN Sunan Kalijaga Yogyakarta, 2010.

${ }^{6}$ Moh. Alex Fawzi, Batas Minimal Usia Perkawinan menurut Undang-undang Nomor 1 Tabun 1974 tentang Perkawinan dalam Perspektif Hukum Islam dan Kesehatan Reproduksi, Skripsi Fakultas Syari'ah dan Hukum UIN Sunan Kalijaga Yogyakarta, 2014.

${ }^{7}$ Andi Sjamsu Alam, Usia perkaninan dalam perspektif filsafat bukum dan kontribusinya bagi pengembangan Hukum perkawinan Indonesia, Disertasi Program Studi Ilmu Filsafat UGM Yogyakarta, 2011.
} 
ketentuan usia perkawinan sebagaimana termaktub dalam Undang-undang Perkawinan No. 1 tahun 1974, dengan menggunakan analisis filsafat hukum diketahui pula bahwa ketentuan itu mengidap persoalan yang tidak mudah diselesaikan. Indikasi problematis usia perkawinan yang paling menonjol muncul ketika dihadapkan pada pasal 7 ayat (2) tentang "dispensasi kawin" yang wewenang yuridis untuk keperluan itu diberikan kepada Pengadilan atau Pejabat lain yang ditunjuk oleh kedua orang tua pihak pria maupun pihak wanita sehingga dinilai mengurangi sakralitas perkawinan. Hukum Islam dalam pemahaman tersebut harus diakui sangat memperhatikan kemaslahatan umat, karena Hukum Islam tidak dapat dipisahkan dari perkembangan masyarakat.

Hukum Islam adalah sesuatu yang paling tinggi dan utama bagi masyarakat muslim. Relevansinya dengan usia perkawinan terletak pada pemaknaan konsep usia perkawinan ideal yang mengacu pada filsafat hukum Islam berlandaskan wahyu Allah SWT dalam alQuran dengan memperhatikan sesungguh-sungguh aspek realitas dalam masyarakat. Merujuk pada ketentuan formal pendewasaan sebagaimana dikenal dalam KUH Perdata, maka 21 (dua puluh satu) tahun dapat ditetapkan sebagai usia perkawinan ideal. Seseorang yang dewasa dianggap mampu berbuat karena memiliki daya yuridis atas kehendaknya sehingga dapat menentukan keadaan hukum bagi dirinya sendiri. Asumsi yang harus dibangun mengacu pada dimensi yang komplementer, baik yang bersifat sosial maupun yang bersifat ekonomi. Bahkan aspek-aspek ini seharusnya dimiliki calon suami-istri sebagai konsekuensi sense of responsibility, baik terhadap pribadi masing-masing maupun bagi keturunan dan lingkungan masyarakatnya.

Penelitian Tesis yang dilakukan oleh Achmad Rifan dengan judul "Dinamika Perkembangan Ketentuan Batas Minimal Usia Perkawinan di Indonesia", dari rumusan masalah dan hasil penelitian tersebut lebih memfokuskan pada perkembangan pembatasan usia perkawinan menurut $\mathrm{UU}^{8}$.

Penelitian yang dilakukan Boga Kharisma, Elman Eddy Patra, Eka Deviani dengan judul "Implementasi Batas Usia Minimal Dalam Perkawinan Berdasarkan UU Nomor 1 Tahun 1974" Penelitian ini lebih memfokuskan pada implementasi UU Perkawinan, dan faktor penghambat dari implementasi tersebut. ${ }^{9}$

Dari beberapa penelitian yang telah ada belum ditemukannya penelitian yang membandingkan Batasan minimal usia perkawinan dalam perspektif hukum positif di Indonesia dan hukum islam, sehingga penelitian ini menjadi penelitian yang baru.

Penelitian ini bertujuan Untuk mengetahui konteks batasan minimal usia perkawinan menurut perspektif hukum positif di Indonesia dan hukum islam serta untuk mengetahui relevansi konteks batasan minimal usia perkawinan dengan konteks sekarang. Penelitian ini diharapkan bisa memberikan kontribusi ilmiah di bidang hukum islam dan pranata sosial dan diharapkan berguna untuk memberikan gambaran atau pedoman awal bagi para praktisi hukum sebagai bahan pertimbangan dalam menetapkan batas usia

8 Achmad Rifan, Dinamika Perkembangan Ketentuan Batas Minimal Usia Perkawinan di Indonesia, (Tesis UIN Sunan Kalijaga, Yogyakarta, 2017)

9 Boga Kharisma, dkk., Implementasi Batas Usia Minimal dalam Perkawinan, (Jurnal Fakultas Hukum Universitas Lampung, 2017). 
minimal perkawinan yang disesuaikan dengan kondisi saat ini, dan juga bisa sebagai bahan kajian untuk penelitian selanjutnya.

\section{Metode Penelitian}

Penelitian ini menggunakan metode penelitian deskriptif analisis dengan menggunakan pendekatan kualitatif yaitu mendeskripsikan dan menganalisis fenomena dan dokumen peraturan perundang-undangan. Penelitian kualitatif disini yaitu gabungan dari studi pustaka dan studi lapangan. Bogdan dan Taylor mendefinisikan metode kualitatif sebagai prosedur penelitian yang menghasilkan data deskriptif berupa kata-kata tertulis atau lisan dari orang-orang. Disebut juga naturalistic sebab peneliti menelaah peristiwa-peristiwa sebagaimana terjadi secara natural, yang datanya dikumpulkan oleh orang-orang yang berperilaku secara apa adanya ${ }^{10}$.

Hasil data tersebut dianalisis sampai data tersebut dianggap kredibel. Sumber data dalam penelitian ini peraturan perundang-undangan tentang perkawinan UU No. 1 tahun 1974 jo. UU No. 16 Tahun 2019 dan buku-buku hukum islam yang membahas tentang perkawinan sebagai sumber data primer dan didukung oleh sumber data sekunder yang berupa literatur dan buku-buku yang terkait.

\section{Analisis Corak Pemikiran Hukum Teologi Asy'ariyyah}

\section{Pengertian Perkawinan}

Menurut Undang-undang pasal (1) No. 1 tahun 1974 perkawinan ialah ikatan lahir batin antara seorang pria dan seorang wanita sebagai suami isteri dengan tujuan membentuk keluarga (rumah tangga) yang bahagia dan kekal berdasarkan Ketuhanan yang Maha Esa.

Menurut pasal 2 Kompilasi Hukum islam perkawinan menurut hukum islam adalah pernikahan, yaitu akad yang sangat kuat atau mitsaqan ghalidzan untuk mentaati perintah Allah dan melaksanakannya merupakan ibadah.

Ulama Syafi'iyah berpendapat bahwa akad menggunakan lafal nikah atau zanj menyimpan arti wati' (hubungan intim). Artinya dengan ikatan pernikahan seseorang dapat memiliki atau mendapatkan kesenangan dari pasangannya. ${ }^{11}$

\section{Batasan Anak dan Usia Dewasa}

Ditinjau dari aspek yuridis, "anak" di mata hukum positif Indonesia lazim diartikan sebagai orang yang belum dewasa (minderjarig/person under age), atau keadaan dibawah umur (minderjarighead/inferiority) atau kerap juga disebut sebagai anak dibawah pengawasan wali (minderjarige ondervoordij).(Nurpratiwi, 2021) Maka, dengan bertitik tolak pada aspek tersebut ternyata hukum positif Indonesia (ius constitutum/ius operatum) tidak

\footnotetext{
${ }^{10}$ Cik Hasan Bisri, Pilar-pilar Penelitian Hukum Islam dan Pranata Sosial, (Jakarta: Raja Grafindo Persada, 2004) 270.

${ }^{11}$ Slamet Dan Aminuddin, Fiqih Munakahat I, (Bandung : CV Pustaka Setia, 1999), 298.
} 
mengatur adanya unifikasi hukum yang baku dan berlaku universal untuk menentukan kriteria batasan umur bagi seorang anak. ${ }^{12}$

Pengertian anak menurut istilah hukum Islam adalah keturunan kedua yang masih kecil $^{13}$. Sifat kecil kalau dihubungkan dengan perwalian hak milik dan larangan bertindak sendiri, sebenarnya ada dua tingkatan yaitu: a) Kecil dan belum mumayyiz dalam hal ini anak itu sama sekali tidak memiliki kemampuan untuk bertindak. Jadi, tidak sah kalau misalnya ia membeli apa-apa atau memberikan apa-apa kepada orang lain. Katakatanya sama sekali tidak dapat dijadikan sebagai pegangan, jadi segala-galanya berada di tangan wali. b) Kecil tapi sudah mumayyiz, dalam hal ini si kecil ini kurang kemampuannya untuk bertindak, namun sudah punya kemampuan, oleh sebab itu katakatanya sudah dapat dijadikan pegangan dan sudah sah kalau ia membeli atau menjual atau memberikan apa-apa kepada orang lain ${ }^{14}$. Dalam hukum Islam, Anak yang Mumayyiz ialah yang sudah mencapai usia mengerti tentang akad transaksi secara keseluruhan dia mengerti maksud kata-kata yang diucapkannya, bahwa membeli itu menerima barang sedang menjual itu memberikan barang dan juga ia menegerti tentang rugi dan beruntung, biasanya usia anak itu sudah genap 7 (tujuh) tahun. ${ }^{15}$

Dalam ilmu psikologi istilah remaja atau adolescence berarti tumbuh atau tumbuh menjadi dewasa, istilah adolescence seperti yang digunakan saat ini memiliki arti yang lebih luas, mencakup kematangan mental, emosional, sosial, dan fisik. ${ }^{16}$ Menentukan batasan usia remaja digunakan secara luas untuk menunjukkan suatu tahapan perkembangan antara masa anak-anak dan dewasa. Penetapan masa usia remaja ini sulit untuk ditentukan, namun pada umumnya para ahli menggunakan usia antara 12 hingga 21 tahun. Rentang waktu usia remaja ini biasanya dibedakan atas tiga, yaitu 12-15 tahun adalah masa remaja awal, 15-18 tahun adalah masa remaja pertengahan, dan 18-21 tahun adalah masa remaja akhir. ${ }^{17}$

Ada beberapa perubahan yang terjadi pada masa usia remaja tersebut, diantaranya ${ }^{18}$ :

a. Kematangan seksual primer (primary sex) yakni menunjuk pada organ tubuh yang secara langsung berhubungan dengan organ reproduksi. Bagi pria ditandai dengan kematangan pada pertumbuhan organ vital yang mencapai kematangan secara penuh diusia 20-21 tahun. Sementara itu pada anak perempuan ditandai dengan munculnya periode menstruasi (menarche). Terjadinya menstruasi pertama kali ini member petunjuk bahwa mekanisme reproduksi anak perempuan telah berfungsi, sehingga memungkinkan mereka untuk mengandung dan melahirkan anak. Secara

\footnotetext{
12 Lilik Mulyadi, Pengadilan Anak di Indonesia, (Bandung: Mandar Maju, 2005), 3-4.

${ }^{13}$ Ensiklopedi Islam, (Jakarta: PT. Ichtiar Baru Van Hoeve), 112.

14 Zakariya Ahmad Al-Barry, Al-Ahkamul Aulad, alih bahasa Chadidjah Nasution, Hukum Anak-anak dalam Islam, (Jakarta: Bulan Bintang, 1997), 113.

${ }^{15}$ Ibid, 114.

16 Elizabeth B. Hurlock, Psikologi Perkembangan Suatu Pendekatan Sepanjang Masa, Penerj. Istiwidayanti dan Soedjarwo, (Jakarta: Erlangga 1980), 206.

${ }^{17}$ Desmita, Psikologi Perkembangan, (Bandung: Remaja Rosdakarya, 2008), 190.

${ }^{18}$ Ibid, 192.
} 
kognitif remaja pada masa usia ini telah mampu menalar untuk mempertimbangkan sesuatu sebelum memutuskan. Kepribadian anak remaja pada intinya masih terdapat sifat kekanak-kanakan, namun pada saat yang sama pula ia mulai sadar akan kebutuhan batiniahnya sendiri, dirinya merupakan sentral pemikiran dan perenungannya.

b. Kematangan seksual sekunder (secondary sex) yakni tanda-tanda jasmaniah yang tidak langsung berhubungan dengan reproduksi dan merupakan perkembangan fisik yang tampak mata.

Sebagaimana masa remaja yang sulit untuk ditentukan batas usianya, begitu pula dengan usia dewasa. Kedewasaan bisa diartikan sebagai satu pertanggungjawaban penuh terhadap diri sendiri, bertanggung jawab atas nasib sendiri dan atas pembentukan diri sendiri. ${ }^{19}$

Arti penting kedewasaan untuk dijadikan ukuran bagi seseorang untuk dinyatakan cakap hukum perlu dikaji secara mendalam sebab sesungguhnya kedewasaan merupakan faktor penting untuk melanggengkan hubungan dalam perkawinan. Oleh karena itu perlu dirumuskan ketentuan usia perkawinan ideal yang didukung oleh selain bukti-bukti ilmiah, juga oleh argumentasi logis sehingga pada gilirannya dapat berfungsi sebagai indikator kedewasaan.

\section{Batas Usia Perkawinan menurut hukum positif di Indonesia}

Dalam pasal 7 (1) UU No. 16 Tahun 2019 Perkawinan hanya diizinkan apabila pria dan wanita sudah mencapai umur 19 (sembilan belas) tahun. Ketentuan ini baru direvisi, sedangkan sebelumnya menurut pasal yang sama UU No. 1 Tahun 1974 perkawinan hanya diizinkan jika pihak pria sudah sudah mencapai umur 19 (sembilan belas) tahun dan pihak wanita sudah mencapai mur 16 (enam belas) tahun.

Pada dasarnya secara umum kedewasaan dijadikan sebagai asas penting oleh pemerintah dalam menetapkan undang-undang perkawinan sebagai hukum positif yang harus dipatuhi oleh semua warga. Selain itu, untuk merevisi dalam menentukan batasan usia yang akan melangsungkan perkawinan pun membutuhkan waktu yang cukup lama yaitu sekitar 45 tahun. Hal ini dilakukan dengan beberapa pertimbangan, salah satunya tertuang dalam konsiderans UU No 16 Tahun 2019 yaitu perkawinan pada usia anak menimbulkan dampak negatif bagi tumbuh kembang anak dan akan menyebabkan tidak terpenuhinya hak dasar anak seperti hak atas perlindungan dari kekerasan dan diskriminasi, hak sipil anak, hak kesehatan, hak pendidikan, dan hak sosial anak.

Penegasan berikutnya tertuang dalam pasal sebelumnya yaitu pasal 6 ayat (1) Undang-undang No. 1 tahun 1974 "untuk melangsungkan perkawinan seorang yang belum mencapai umur 21 (dua puluh satu) tahun harus mendapat izin kedua orang tua". Meskipun Batasan usia minimal yang akan melangsungkan perkawinan menurut UU adalah usia 19 tahun, tetapi dalam pasal ini ditentukan kembali bagi mereka yang belum

${ }^{19}$ Kartini Kartono, Psikologi Wanita Mengenal Gadis Remaja dan Wanita Dewasa, Jilid I, (Bandung: Mandar Maju, 2006), 172. 
mencapai umur usia 21 tahun harus mendapatkan izin dari kedua orang tua. Apabila dikaitkan dengan pendapat Desmita (2008) bahwa usia 18-21 tahun itu belum termasuk kedalam kategori dewasa akan tetapi masih tergolong kedalam tahap remaja akhir, hal ini bisa saja dijadikan sebagai pertimbangan dalam menetapkan pasal 6 ayat (1) dalam UU ini. Izin orang tua bagi mereka yang belum mencapai usia 21 tahun yang dimaksud adalah dengan mengisi N4 yang sudah disiapkan oleh Kantor Urusan Agama.

\section{Batas Usia Perkawinan Menurut Hukum Islam}

Pada dasarnya, Hukum Islam tidak mengatur secara mutlak tentang batas umur perkawinan. Tidak adanya ketentuan agama tentang batas umur minimal dan maksimal untuk melangsungkan perkawinan diasumsikan memberi kelonggaran bagi manusia untuk mengaturnya. Al-Qur'an mengisyaratkan bahwa orang yang akan melangsungkan perkawinan haruslah orang yang siap dan mampu. Sebagaimana dalam Q.S An-Nur: 32

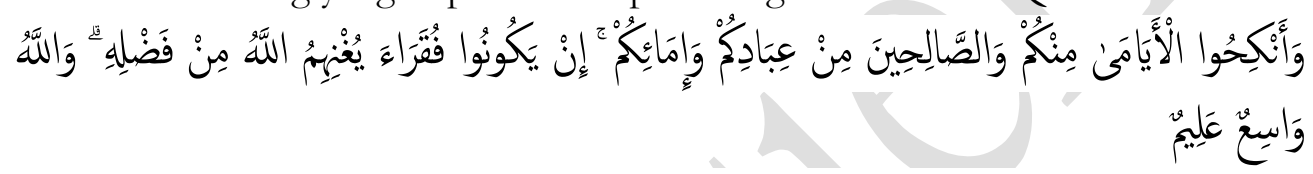

Artinya: "Dan kawinkanlah orang-orang yang sendirian diantara kamu, dan orang-orang yang layak (berkawin) dari hamba-hamba sahayamu yang lelaki dan hamba-hamba sabayamu yang perempuan. Jika mereka miskin Allah akan memampukan mereka dengan kurnia-Nya. Dan Allab maha luas (pemberiannya) lagi maha mengetabui."

Dalam ayat tersebut tidak dijelaskan dengan batasan usia, hanya disebutkan orangorang yang layak menikah, dan ini diterjemahkan sebagai orang yang mampu baik dari segi mental (psikologis), fisikal (biologis), sosial (ekonomi dan Pendidikan) maupun spiritual.

Adapun syarat perkawinan agak tersamar dengan rukun perkawinan itu sendiri (calon suami, calon istri, wali nikah, dua orang saksi dan ijab qabul), sebagaimana kita ketahui syarat dan rukun itu berbeda. Menurut ilmu fiqih calon suami atau istri harus memiliki identitas seksual yang jelas sebagai pria atau wanita, dan keduanya harus terbebas dari halangan perkawinan. ${ }^{20}$

Perkawinan yang dilakukan oleh anak dibawah umur tidak terlepas dari hak ijbar wali mujbir (wali yang boleh memaksa anaknya untuk menikah). Hal ini sebagaimana yang diceritakan oleh Aisyah R.A dalam sebuah hadits yang diriwayatkan oleh Bukhari dan Muslim.

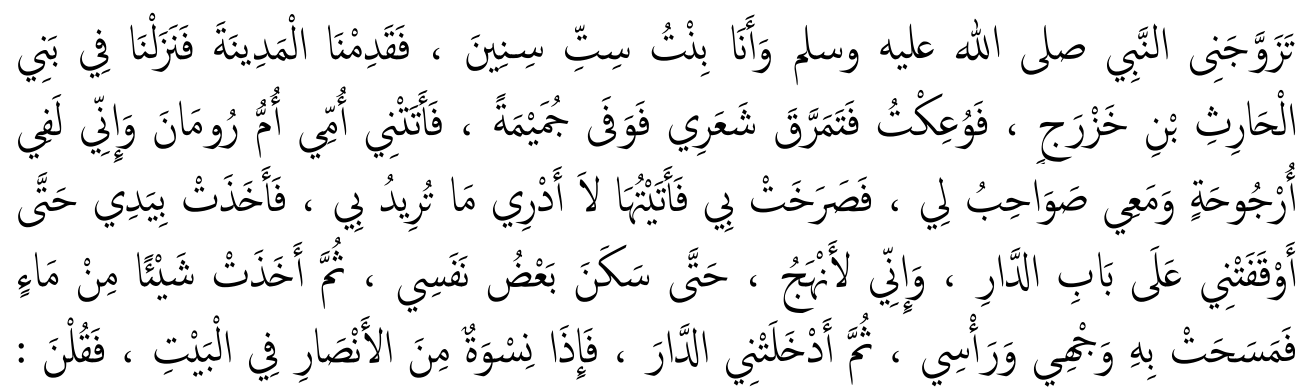

${ }^{20}$ Rahmat Hakim, Hukum Perkawinan Islam, (Bandung: CV Pustaka Setia, 1999), 82. 


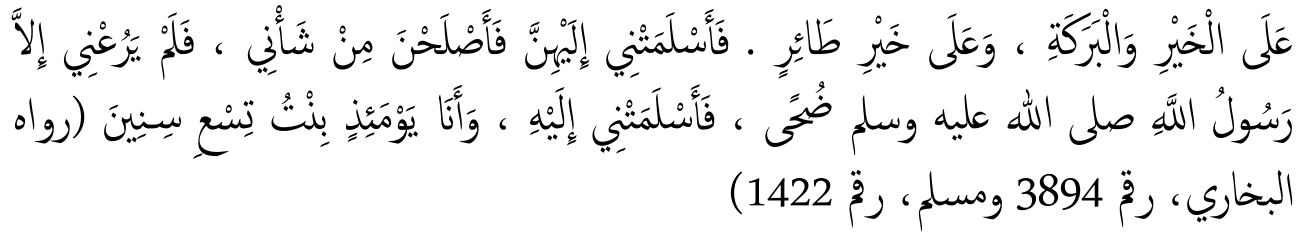

"Aku dinikabi oleh Nabi shallallabu alaibi wa sallam saat aku berusia 6 tabun. Lalu kami datang ke Madinah, dan kami tinggal di Bani Harits bin Khąraj. Lalu aku menderita sakit sehingga rambutku rontok kemudian banyak lagi. Lalu ibuku, Ummu Ruman, mendatangiku saat aku berada di ayunan bersama teman-temanku. Lalu dia memanggilku, maka aku mendatanginya, aku tidak tabu apa yang dia inginkan. Maka dia mengajakku bingga aku tiba di depan pintu sebuah rumah. Aku sempat merasa khawatir, namun akhirnya jiwaku tenang. Kemudian ibuku mengambil sedikit air dan mengusapkannya ke wajah dan kepalaku. Kemudian dia mengajakku masuk ke rumah tersebut. Ternyata di dalamnya terdapat beberapa orang wanita kaum Anshar. Mereka berkata, "Selamat dan barokah, selamat dengan kebaikan." Lalu ibuku menyerabkanku kepada mereka dan kemudian mereka mulai merapibkan aku. Tidak ada yang mengagetkan aku kecuali kedatangan Rasulullab shallallahu alaibi wa sallam pada waktu Dhuba. Kemudian ibuku menyerabkan aku kepadanya dan ketika itu aku berusia 9 tabun." (HR. Bukhari, No. 3894, Muslim, No. 1422)

Secara tidak langsung, Al-Qur'an dan Hadits mengakui bahwa kedewasaan sangat penting dalam perkawinan. Usia dewasa dalam figh ditentukan dengan tanda-tanda yang bersifat jasmani yaitu tanda-tanda baligh secara umum antara lain, sempurnanya umur 15 (lima belas) tahun bagi pria, ibtilam bagi pria dan haid pada wanita minimal pada umur 9 (sembilan) tahun. Dengan terpenuhinya kriteria baligh maka telah memungkinkan seseorang melangsungkan perkawinan. Sehingga kedewasaan seseorang dalam Islam sering diidentikkan dengan baligh. ${ }^{21}$

\section{Relevansi Konteks Batasan Minimal Usia Perkawinan dengan konteks Sekarang}

Undang-undang perkawinan kini mengalami perubahan setelah kurang lebih 45 tahun sejak disahkannya Undang-undang perkawinan pada Tahun 1974. Meskipun tidak semua pasal yang direvisi, dan hanya pasal 7 yang berkaitan dengan usia bagi orang yang akan melangsungkan perkawinan. Kini antara pria dan wanita tidak ada perbedaan tentang usia ini, karena UU No. 16 Tahun 2019 menetapkan perkawinan diizinkan bagi pria dan wanita yang sudah mencapai umur 19 tahun. Berbeda dengan undang-undang perkawinan sebelumnya yang menetapkan batas usia perkawinan antara pria dan wanita itu berbeda, yaitu pria 19 tahun dan wanita 16 tahun.

Menurut pandangan penulis konteks batas minimal usia perkawinan sudah relevan dengan kondisi saat ini, dan juga dengan undang-undang lain yang berkaitan, salah satunya adalah undang-undang perlindungan anak. Dalam Undang-undang perlindungan anak No. 23 Tahun 2002 Jo. UU 35 Tahun 2014 "Anak adalah seseorang yang belum berusia 18 (delapan belas) tahun, termasuk anak yang masih berada dalam kandungan". Undang-undang perkawinan sebelumnya menetapkan batas usia wanita yang akan melangsungkan perkawinan itu 16 tahun, dan hal ini secara tidak langsung bertentangan dengan undang-undang perlindungan anak yang sudah ditetapkan tahun 2002, tetapi ru

${ }^{21}$ Amir Syarifuddin, Ushul Fiqh, Jilid I, (Jakarta : Prenada Media, 2008, Cet. III), 394 
tahun 2019 undang-undang itu direvisi dengan salah satu pertimbangannya adalah perlindungan anak.

Terhadap relevansi konteks batas minimal usia perkawinan ini, ada sebagian kalangan yang menganggap belum relevan dengan kondisi saat ini. Sebagaimana yang diungkapkan oleh Ahmad Masfuful Fuad (2015) dalam tesisnya yang berjudul Ketentuan

Usia Minimal Kawin dalam UU Nomor 1 Tahun 1974 (Studi Perspektif Hermeneutika): Sudah saatnya standar batas minimal usia kawin yang tertera dalam pasal 7 ayat (1) Undang-undang perkawinan dinaikkan standarnya. Pasal yang menyatakan bahwa perkawinan hanya diizinkan apabila calon mempelai laki-laki telah berusia 19 dan calon mempelai perempuan berusia 16 tahun, sudah tidak relevan lagi di masa sekarang baik dari sisi kesehatan biologis, psikologis, ekonomi, Pendidikan, dan kebudayaan. Sehingga baik calon mempelai laki-laki dan perempuan setidaknya telah genap berusia 21 tahun jika hendak melangsungkan perkawinan.

Meskipun yang menjadi acuannya tersebut undang-undang perkawinan tahun 1974, tetapi pandangannya terhadap ketidakrelevan dengan konteks saat ini karena memberikan pendapat bahwasannya seharusnya batasan usia perkawinan itu adalah 21 tahun, sedangkan menurut undang-undang yang telah ditetapkan adalah 19 tahun.

\section{E. Simpulan}

Batas usia perkawinan menurut perspektif hukuman positif di Indonesia yang dalam hal ini adalah UU No. 1 Tahun 1974 Jo. UU No. 16 Tahun 2019 sebagai Undang-undang terkait dengan perkawinan adalah 19 tahun dan ini berlaku baik bagi pria maupun wanita. Batas usia perkawinan menurut perspektif hukum islam tidak adanya ketentuan yang memberikan batasan usia minimal, tetapi dalam hukum islam hanya ditegaskan bagi mereka yang sudah mencapai usia baligh, dengan tanda-tanda secara umum antara lain, sempurnanya umur 15 (lima belas) tahun bagi pria, ibtilam bagi pria dan haid pada wanita minimal pada umur 9 (sembilan) tahun. Batas usia minimal perkawinan sudah relevan konteks saat ini dan juga sudah sesuai dengan undang-undang lain yang terkait, yaitu salah satunya undang-undang perlindungan anak yang memberikan batasan usia anak itu sampai usia 18 tahun.

\section{DAFTAR PUSTAKA}

Alam, Andi Sjamsu. (2011). Usia Perkawinan dalam Perspektif Filsafat Hukum dan Kontribusinya bagi Pengembangan Hukum Perkawinan Indonesia". Disertasi, Program Studi Ilmu Filsafat UGM. Yogyakarta.

Al-Barry, Zakariya Ahmad Al-Barry. (1997). Al-Abkamul Aulad, alih bahasa Chadidjah Nasution, Hukum Anak-anak dalam Islam, Jakarta: Bulan Bintang.

Arif, Agus Sanwani. (2010). Batas Umur Minimal Perkawinan (Studi Perbandingan Kompilasi Hukum Islam dan Psikologi). Skripsi, Fakultas Syari'ah dan Hukum UIN Sunan Kalijaga, Yogyakarta.

Bisri, Cik Hasan. (2006). "Menata Penelitian Antardisiplin dan Multidisiplin di Kalangan Sivitas Akademika UIN Bandung", dalam Research University konsep dan Model Kajian 
Keilmuan dalam Pengembangan UIN Sunan Gunung Djati Bandung. Bandung: Suguda Press.

. (2004). Pilar-pilar Penelitian Hukum Islam dan Pranata Sosial, Jakarta: Raja Grafindo Persada.

Desmita. (2008). Psikologi Perkembangan, Bandung: Remaja Rosdakarya.

Ensiklopedi Islam. Jakarta: PT. Ichtiar Baru Van Hoeve.

Fawzi, Moh. Alex. (2014). Batas Minimal Usia Perkawinan menurut Undang-undang Nomor 1 Tabun 1974 tentang Perkawinan dalam Perspektif Hukum Islam dan Kesehatan Reproduksi, Skripsi Fakultas Syari'ah dan Hukum UIN Sunan Kalijaga. Yogyakarta.

Hakim, Rahmat. (2000). Hukum Perkawinan Islam, Bandung: CV Pustaka Setia.

Hamdani. (1995). Risalah Hukum Perkawinan Islam. Jakarta: Citra Karsa Mandiri.

Hurlock, Elizabeth B. (1980). Psikologi Perkembangan Suatu Pendekatan Sepanjang Masa. Penerj. Istiwidayanti dan Soedjarwo, Jakarta: Erlangga.

Jahar, Asep Saepuddin. Dkk. (2013). Hukum Keluarga, Pidana \& Bisnis; Kajian Perundangundangan Indonesia, Fikih dan Hukum Internasional. Jakarta: Kencana.

Kartono, Kartini. (2006). Psikologi Wanita Mengenal Gadis Remaja dan Wanita Dewasa. Jilid I. Bandung: Mandar Maju.

Kharisma, Boga dkk. (2017). Dalam jurnal Fakultas Hukum Implementasi Batas Usia Minimal dalam Perkawinan. Lampung.

Mu'ala, Asyharul. (2010). Batas minimal Usia Nikah Perspektif Mubammadiyah dan Nahdlatul Ulama Fakultas Syari'ah dan Hukum UIN Sunan Kalijaga Yogyakarta.

Mulyadi, Lilik. (2005). Pengadilan Anak di Indonesia. Bandung: Mandar Maju.

Penyusun. (2001). Kompilasi Hukum Islam Di Indonesia. Jakarta: Direktorat Pembinaan Badan Peradilan Agama.

Ridla, Muhammad Rasyid. Tth. Tafsir al-Mannar IV. Kairo: Maktabah al Qahirah.

Rif an, Achmad. (2017) Dinamika Perkembangan Ketentuan Batas Minimal Usia Perkawinan di Indonesia. 2017. Tesis UIN Sunan Kalijaga, Yogyakarta.

Slamet Dan Aminuddin. (1999). Fiqih Munakahat I, Bandung: CV Pustaka Setia.

Soemiyati. (1989). Hukum Perkawinan Islam dan Undang-undang Perkawinan, Yogyakarta: Liberty Yogyakarta.

Nurpratiwi, M. R. E. dan S. (2021). Hubungan Keberagamaan dan Perilaku Altruistik

Mahasiswa. Al-Afkar, 4(1), 83-97.

https://doi.org/https://doi.org/10.31943/afkarjournal.v4i1.181

Effendi, M. R., \& Nurpratiwi, S. (2021). H Hubungan Keberagamaan dan Perilaku Altruistik Mahasiswa. al-Afkar, Journal For Islamic Studies, 4(1).

Sumbulah, Umi (2007). Ketentuan perkawinan dalam KHI dan Implikasinya bagi Fikih Mu'asyarab: Sebuah Analisis Gender. Diakses tanggal 16 Agustus 2019, dari http://ejournal.uinmalang.ac.id/indx.php/egalita

Syarifuddin, Amir. (2008). Ushul Figh. Jilid I. Cet. III. Jakarta: Prenada Media.

Undang-undang Nomor 1 Tahun 1974 Tentang Perkawinan

Undang-Undang Nomor 16 Tahun 2019 Tentang Perubahan atas Undang-undang Nomor 1 Tahun 1974 Tentang Perkawinan

Undang-undang Nomor 23 Tahun 2002 tentang Perlindungan Anak 